\title{
Off-hour presentation and outcomes in patients with acute myocardial infarction: systematic review and meta-analysis
}

\author{
(c) $(1)$ (1) OPEN ACCESS
}

\begin{abstract}
Atsushi Sorita senior fellow in preventive medicine and public health ${ }^{1}$, Adil Ahmed senior research fellow $^{2}$, Stephanie R Starr consultant physician ${ }^{3}$, Kristine M Thompson consultant physician ${ }^{4}$, Darcy A Reed consultant physician ${ }^{5}$, Larry Prokop reference librarian ${ }^{6}$, Nilay D Shah senior associate consultant $^{7}$, M Hassan Murad consultant physician ${ }^{1}$, Henry $\mathrm{H}$ Ting consultant physician ${ }^{8}$
\end{abstract}

${ }^{1}$ Division of Preventive Medicine, Mayo Clinic, Rochester, MN, USA; ${ }^{2}$ Division of Pulmonary and Critical Care, Mayo Clinic, Rochester, MN, USA; ${ }^{3}$ Division of Community Pediatric and Adolescent Medicine, Mayo Clinic, Rochester, MN, USA; ${ }^{4}$ Department of Emergency Medicine, Mayo Clinic, Jacksonville, FL, USA; ${ }^{5}$ Division of Primary Care Internal Medicine, Mayo Clinic, Rochester, MN, USA; ${ }^{6}$ Mayo Clinic Libraries, Mayo Clinic, Rochester, MN, USA; ${ }^{7}$ Division of Health Care Policy and Research, Mayo Clinic, Rochester, MN, USA; ${ }^{8}$ Division of Cardiovascular Diseases, Mayo Clinic, 200 First Street SW, Rochester, MN 55905, USA

\begin{abstract}
Objective To assess the association between off-hour (weekends and nights) presentation, door to balloon times, and mortality in patients with acute myocardial infarction.

Data sources Medline in-process and other non-indexed citations, Medline, Embase, Cochrane Database of Systematic Reviews, and Scopus through April 2013.
\end{abstract}

Study selection Any study that evaluated the association between time of presentation to a healthcare facility and mortality or door to balloon times among patients with acute myocardial infarction was included.

Data extraction Studies' characteristics and outcomes data were extracted. Quality of studies was assessed with the Newcastle-Ottawa scale. A random effect meta-analysis model was applied. Heterogeneity was assessed using the $Q$ statistic and $\mathrm{I}^{2}$.

Results 48 studies with fair quality, enrolling 1896859 patients, were included in the meta-analysis. 36 studies reported mortality outcomes for 1892424 patients with acute myocardial infarction, and 30 studies reported door to balloon times for 70534 patients with ST elevation myocardial infarction (STEMI). Off-hour presentation for patients with acute myocardial infarction was associated with higher short term mortality (odds ratio 1.06, 95\% confidence interval 1.04 to 1.09). Patients with STEMI presenting during off-hours were less likely to receive percutaneous coronary intervention within 90 minutes (odds ratio 0.40 , 0.35 to 0.45$)$ and had longer door to balloon time by $14.8(95 \%$ confidence interval 10.7 to 19.0) minutes. A diagnosis of STEMI and countries outside North America were associated with larger increase in mortality during off-hours. Differences in mortality between off-hours and regular hours have increased in recent years. Analyses were associated with statistical heterogeneity.

Conclusion This systematic review suggests that patients with acute myocardial infarction presenting during off-hours have higher mortality, and patients with STEMI have longer door to balloon times. Clinical performance measures may need to account for differences arising from time of presentation to a healthcare facility.

\section{Introduction}

Acute myocardial infarction remains a leading cause of death worldwide. ${ }^{1}$ Every year, approximately one million people in the United States have an acute myocardial infarction and 400 000 die from coronary heart disease. ${ }^{2}$ Previous studies have suggested that patients with acute myocardial infarction who present to the hospital during off-hours (weekends and nights) may have higher mortality. ${ }^{3-6}$ Higher mortality during off-hours may be attributed to a lower likelihood of receiving evidence based treatment or timely reperfusion therapies. ${ }^{67}$ Furthermore, the number of hospital staff and their level of expertise may contribute to gaps in the quality of care during off-hours. ${ }^{48}$ Because of the high incidence and case fatality of acute myocardial infarction, small increases in the relative risk of mortality during off-hours can translate to important effects in the population.

Using data from the National Registry of Myocardial Infarction database, Magid et al showed that patients with ST elevation 
myocardial infarction (STEMI) who presented during off-hours had higher in-hospital mortality and longer door to balloon times. ${ }^{6}$ Kostis et al examined an administrative database in New Jersey and found that weekend admissions for patients with acute myocardial infarction were associated with higher in-hospital, 30 day, and one year mortality. ${ }^{4}$ Conversely, Jneid et al reported no significant difference in mortality between off-hours and regular hours for acute myocardial infarction patients in the Get With the Guidelines-Coronary Artery Disease (GWTG-CAD) national database, despite longer door to balloon times in off-hours for patients with STEMI. ${ }^{10}$ Other studies have also reported inconsistent results. ${ }^{11-16}$

To date, no systematic reviews or meta-analyses of this literature have been done. Therefore, we aimed to synthesize the available evidence on the effects of off-hour presentation of patients on outcomes of acute myocardial infarction. Our primary outcome was the difference in-hospital or 30 day mortality for patients with acute myocardial infarction who presented during off-hours compared with those who presented during regular hours. The secondary outcome was door to balloon time for patients with STEMI.

\section{Methods}

This study was conducted according to guidance from the Cochrane Handbook of Systematic Reviews and is reported according to PRISMA (preferred reporting items for systematic reviews and meta-analyses) recommendations. ${ }^{17} 18$

\section{Data sources and search strategies}

We did a comprehensive search of several databases from database inception to April 2013, any language. The databases included Ovid Medline in-process and other non-indexed citations, Ovid Medline, Ovid Embase, Ovid Cochrane Database of Systematic Reviews, and Scopus. An experienced librarian designed and conducted the search strategy with input from the principal investigator. He used controlled vocabulary supplemented with keywords to search for comparative studies of off-hour effects for patients with acute myocardial infarction. The strategy is available in the web appendix (table A). We also manually searched PubMed, Ovid Medline, and references in pertinent articles that were identified in the screening processes.

\section{Study selection}

We considered all studies published in any language, with any study design, that evaluated the association between time of presentation and mortality or door to balloon times among adult patients who presented with acute myocardial infarction. Studies were eligible if they compared the outcomes between patients with off-hour versus regular hour presentation. We categorized the comparison of off-hours versus regular hours as weekend and night versus weekday regular hours, weekend versus weekday, or night versus daytime (appendix figure A). Time of presentation could be measured by arrival at the hospital, admission to hospital, or start of percutaneous coronary intervention. Eligible mortality outcomes included in-hospital mortality and 30 day mortality. Initial screening of abstracts excluded non-relevant or non-original studies. We then used full text screening to assess eligibility. Whenever reports pertained to the same set of patients, we retained the one with the most recent year of publication to obtain the most updated data. Two investigators (AS and AA) independently screened reports. Studies with discrepant decisions in screening of the abstract proceeded to full text screening. We resolved discrepancies in full text screening through consensus. We calculated a $\kappa$ statistic to quantify the agreement between the two reviewers on study selection.

\section{Data extraction}

We recorded information on studies' characteristics and demographics such as authors, publication year, country, years of enrollment of the cohort, data source, the definition of off-hours and regular hours, time of presentation measured for allocation, and the inclusion and exclusion criteria, as well as per group sample size, characteristics of the population, variables adjusted for, and outcomes. We recorded mortality by either number or proportion of deaths in each group and odds ratio or hazard ratio with confidence intervals. We recorded door to balloon time by either mean with standard deviation or median with interquartile range or by the proportion of patients whose door to balloon time was 90 minutes or less. For studies that implemented an intervention that could affect the outcome, we abstracted data from the observational (pre-intervention) period. One investigator abstracted data, which a second investigator independently verified. The discrepancies found in the verification process were solved by consensus or further review by a third investigator. SRS, DAR, and KMT abstracted data, and AS and AA verified data.

\section{Assessment of methodological quality}

We assessed the methodological quality of the included studies by using the Newcastle-Ottawa scale. ${ }^{19}$ This scale consists of three domains (cohort selection, comparability, and outcome) and evaluates the study's overall risk of bias. The maximum score for an observational study is 9 points. Two investigators independently assessed quality, and another resolved discrepancies.

\section{Outcome definition and subgroup analyses Mortality outcomes}

We used in-hospital or 30 day mortality as the main outcome. For studies without in-hospital mortality results, we used 30 day mortality when available. We did the main analysis for all studies combined. We also separately analyzed each mortality outcome (in-hospital versus 30 day). For the main outcome, we did subgroup analyses by diagnosis of patient cohort (STEMI versus non-STEMI), type of off-hours (weekend and night versus weekend versus night), measured time of presentation (arrival versus admission versus start of percutaneous coronary intervention), data source (clinical registry versus administrative data), region (North America versus Europe versus others), and outcome adjustment (adjusted versus unadjusted). To evaluate the possibility of a time trend effect of mortality across studies, we did meta-regression using the mid-year of enrollment of the cohort as the independent variable and the natural log of the effect size as the dependent variable. Owing to concern about potential overlapping patient sets, we did sensitivity analyses by excluding each single cohort and by including only one cohort from each study. We also did sensitivity analyses by excluding studies that expressed results as a hazard ratio.

\section{Door to balloon time}

We analyzed the proportion of patients with STEMI whose door to balloon time was less than 90 minutes and the mean or median door to balloon times. For mean or median door to balloon times, we did subgroup analyses by type of off-hours determination, measured time of presentation, and region, as well as meta-regression using the mid-year of enrollment of the cohort to evaluate time trends in door to balloon times. We also did 
sensitivity analyses limiting to studies that included only patients who were directly admitted to the hospital and excluding interventional studies.

\section{Statistical analysis}

For the mortality outcome, we retrieved or calculated the adjusted odds ratio and corresponding $95 \%$ confidence interval from each study. When adjusted estimates were unavailable, we used unadjusted ones. When a hazard ratio was reported, we considered it to approximate the relative effect measure reported in other studies that used odds ratios and tested this assumption in sensitivity analysis. For door to balloon times, we retrieved or calculated odds ratios with $95 \%$ confidence intervals for the proportion of patients who received percutaneous coronary intervention within 90 minutes. We estimated the mean difference and $95 \%$ confidence interval from the mean and standard deviation. When the standard deviation was not reported, we imputed it by using the methods reported in the Cochrane Handbook for Systematic Reviews. ${ }^{18}$

We used the $\mathrm{I}^{2}$ statistic to estimate the percentage of total variation across studies due to heterogeneity rather than chance (ranging from $0 \%$ to $100 \%$ ). ${ }^{20}{ }^{21} \mathrm{I}^{2}$ values of $25 \%$ or less, $50 \%$, and $75 \%$ or greater represent low, moderate, and high inconsistency. We used the random effect model to pool results across studies, accounting for between study variance. ${ }^{22} \mathrm{We}$ chose this model because of anticipated significant heterogeneity between studies in terms of population and methods used to ascertain outcomes. We used the Q statistic to assess the presence of statistically significant heterogeneity. To assess the potential effect of publication bias, we inspected funnel plots for asymmetry and used the Duval and Tweedie trim and fill method and the Begg and Mazumdar rank correlation test. ${ }^{23}{ }^{24}$

We used Comprehensive Meta-Analysis, version 2 (Englewood, New Jersey) for statistical analysis. All P values are two tailed, and we set $\mathrm{P}<0.05$ as the threshold for significance.

\section{Results}

We retrieved 487 citations; 48 studies met the inclusion criteria and provided data for 1896859 participants (fig $1 \Downarrow$ ). ${ }^{3-6} 10-16$ 25-61 All of the studies had a cohort design; no case-control studies met the inclusion criteria. Four studies implemented an intervention during the study period and reported only door to balloon outcomes. ${ }^{25-28}$ The $\kappa$ statistic was 0.77 for abstract screening and 0.72 for full text screening. Table $1 \Downarrow$ shows details of the studies' characteristics.

The year of publication ranged from 2001 to 2013, and the patient cohort included in the studies started as early as 1987. Six studies reported acute myocardial infarction outcomes as a subset of a patient cohort including other diagnoses. ${ }^{3} 1130323842$ A total of 20 studies took place in North America (United States and Canada) and 18 studies in Europe. Among the studies outside those two regions, two studies were written in a foreign language (Portuguese). ${ }^{37} 40$ The largest study included 922074 Medicare patients. ${ }^{11}$ A total of 15 studies used time of arrival at the hospital or emergency department for categorization of off-hour presentation, and 18 studies used admission time. Fifteen studies used time of start of percutaneous coronary intervention and thus included only patients who had such an intervention. Clinical registries and administrative data (through ICD (international classification of diseases) code or other coding system) were the main sources of data in 38 and 10 studies, respectively. Detailed quality ratings of study quality according to the Newcastle-Ottawa criteria are available in the appendix (table B). Thirty studies were deemed to have fair quality (low to moderate risk of bias, with 8 or more points on the quality scale).

\section{Mortality}

A total of 36 studies reported in-hospital or 30 day mortality and provided data for 1892424 participants. Of these, 24 studies reported in-hospital mortality, seven studies reported 30 day mortality, and five studies reported both. Two studies reported results stratified by years of patient cohort, ${ }^{47}$ so each cohort was analyzed separately, resulting in 42 cohorts for the main analysis. Thirty cohorts reported adjusted mortality, and 12 reported unadjusted mortality. Off-hour presentation was associated with significantly higher in-hospital or 30 day mortality across all cohorts (odds ratio $1.06,95 \%$ confidence interval 1.04 to $1.09 ; \mathrm{I}^{2}=74 ; 42$ cohorts) (fig $2 \Downarrow$ ). Off-hour presentation was also associated with higher in-hospital mortality (odds ratio $1.05,1.03$ to $1.08 ; \mathrm{I}^{2}=55 ; 35$ cohorts) and 30 day mortality $\left(1.05,1.02\right.$ to $1.09 ; \mathrm{I}^{2}=83 ; 18$ cohorts) (appendix figures $\mathrm{B}$ and $\mathrm{C}$ ). A diagnosis of STEMI (odds ratio $1.12,1.03$ to $1.22 ; \mathrm{I}^{2}=42 ; 25$ cohorts) was associated with a larger increase in in-hospital or 30 day mortality during off-hours than was non-STEMI $\left(0.96,0.91\right.$ to $1.02 ; \mathrm{I}^{2}=0 ; 2$ cohorts). Studies in Europe (odds ratio 1.08, 1.02 to $1.15 ; \mathrm{I}^{2}=53$; 18 cohorts) and other regions $\left(1.25,1.15\right.$ to $1.36 ; \mathrm{I}^{2}=15 ; 8$ cohorts) seemed to be associated with a larger increase in mortality during off-hours than were North American studies (1.03, 1.01 to $1.04 ; I^{2}=49 ; 15$ cohorts). We found no significant interaction between outcome adjustment and increase in mortality during off-hours (adjusted odds ratio 1.07, 1.04 to $1.10 ; \mathrm{I}^{2}=75 ; 30$ cohorts versus unadjusted odds ratio $1.19,0.98$ to $1.44 ; \mathrm{I}^{2}=48 ; 12$ cohorts). Otherwise, the remaining subgroup analyses were not statistically significant (table $2 \Downarrow$ ).

Meta-regression showed a significant association between the mid-year of patient enrollment and the effect size, suggesting a larger off-hour increase in mortality in recent years $(\mathrm{P}=0.03)$ (appendix figure D). Sensitivity analyses did not alter the main outcome.

Visual inspection of the funnel plot including all cohorts showed asymmetry favoring positive association between off-hour presentation and higher mortality in small studies (appendix figure E). The Begg-Mazumdar test was not statistically significant $(\mathrm{P}=0.052)$. With the trim and fill approach, the imputed estimate was identical to that in the main analysis. However, assessment of publication bias was limited in the setting of heterogeneous effect size.

\section{Door to balloon time}

Door to balloon time was reported in 30 studies, providing data for 70534 patients with STEMI. Of these studies, 23 reported mean or median door to balloon times, two reported the proportion of patients with door to balloon times within 90 minutes, and five reported both. One study reported median door to balloon times for two separate cohorts for weekend and night, and each result was analyzed separately. ${ }^{5}$ Thus, a total of 29 cohorts were available for the mean difference analyses. Patients who presented during off-hours were less likely to receive percutaneous coronary intervention within 90 minutes than were those who presented during regular hours (odds ratio $0.40,0.35$ to $0.45 ; \mathrm{I}^{2}=41 ; 7$ cohorts) (fig $3 \Downarrow$ ). The door to balloon time was longer in patients who presented during off-hours by 14.8 (95\% confidence interval 10.7 to 19.0$)$ minutes $\left(\mathrm{I}^{2}=99 ; 29\right.$ cohorts) (appendix figure F). Off-hour presentation was associated with longer door to balloon time in all of the studied subgroups, and measured time of presentation and regions of the cohorts were significant for interaction (table $3 \Downarrow$ ). 
Meta-regression did not show a significant time trend effect on the difference in door to balloon time $(\mathrm{P}=0.23)$. Tests for publication bias were not statistically significant, although this conclusion is also limited by heterogeneity. Sensitivity analyses did not alter the above outcomes.

\section{Discussion}

This systematic review and meta-analysis shows that patients with acute myocardial infarction who presented during off-hours had higher mortality than did those who presented during regular hours. Higher mortality during off-hours was seen for both in-hospital and 30 day mortality. The difference in mortality may be larger for patients with a diagnosis of STEMI and for a non-North American location of the study and may have worsened in recent years.

\section{Comparison with other studies}

This review showed that patients with STEMI were less likely to receive percutaneous coronary intervention within 90 minutes and had longer door to balloon times during off-hours. An approximate 30 minute delay in door to balloon time is associated with a 20-30\% relative increase in in-hospital morality for STEMI patients, regardless of the baseline door to balloon time up to 180 minutes. ${ }^{62}{ }^{63}$ Therefore, the 15 minute increase in door to balloon time observed during off-hours could increase mortality by as much as $10-15 \%$, assuming linearity between door to balloon time and mortality. This is consistent with our point estimate of $12 \%$ increase in odds of mortality for STEMI, which suggests that the mortality increase in off-hours may well be partially explained by prolonged door to balloon times. Magid et al reported that the difference in mortality became non-significant when adjusted for reperfusion treatment time. ${ }^{6}$ Additionally, a lower rate of urgent percutaneous coronary intervention for STEMI patients may also partially explain higher mortality during off-hours. ${ }^{464}$

Difference in door to balloon times and rate of percutaneous coronary intervention is likely associated with availability of cardiologists, support staff for the cardiac catheterization laboratory, or both. An around the clock on-site cardiology service is not uniformly available. During off-hours, many institutions need to assemble on-call staff and cardiologists to activate the cardiac catheterization laboratory. This is well illustrated in Magid's study, ${ }^{6}$ in which the increase in the time interval from obtaining an electrocardiogram to arriving at the catheterization laboratory explained nearly all of the increases in door to balloon time during off-hours.

Other potential attributes to the increase in mortality during off-hours are availability of skilled staff in the cardiac care unit, availability of diagnostic tests, number of physicians or nursing staff, and human factors such as sleep deprivation and fatigue. ${ }^{65-68}$ A recent study found that patients with acute myocardial infarction in regions with a low density of cardiologists had higher 30 day mortality than did patients in regions with a high density, suggesting that the availability of cardiologists in the regional system of care may affect the outcomes of patients with acute myocardial infarction. ${ }^{69}$ Holmes et al reported that a successful regional care model can reduce the disparity of care between off-hours and regular hours for patients with STEMI. ${ }^{27}$ Therefore, establishing a local healthcare delivery system to provide consistent quality of care during weekends and nights may be the key to closing the mortality gap between off-hours and regular hours.

An alternative explanation for the increase in mortality during off-hours may be that the case mix differs between off-hours and regular hours. Some studies included in the meta-analysis show that patients who present during off-hours tend to be sicker when measured by the presence of cardiogenic shock or Killip class, ${ }^{63644}$ whereas others suggest no difference. ${ }^{12} 1541525361$ In studies that measured time from onset of symptoms to presentation at hospital, the pre-hospital delay during off-hours was shorter, ${ }^{30} 3654$ longer, ${ }^{5}$ or not different, ${ }^{12} 163133353744485357$ compared with regular hours. In fact, past studies showed that the pre-hospital delay was shorter during off-hours in both STEMI and non-STEMI patients. ${ }^{70}{ }^{71}$ Furthermore, in studies in which mortality outcomes were adjusted (see table $1 \Downarrow$ for adjusted variables), the off-hours increase in mortality remained significant (table $2 \Downarrow$ ). Although residual confounding resulting from the difference in case mix cannot be excluded, these results suggest that increased mortality during off-hours is associated with factors that arise after presentation at hospital.

In meta-regression, we noted a significantly higher difference in mortality between off-hours and regular hours in the most recent years. We postulate that this may be due to the increase in shift work or hand-offs for off-hour coverage or to disproportionate improvement in the application of evidence based treatment during regular hours compared with off-hours; however, this could be also a chance finding and is certainly subject to ecological bias. In contrast, the difference in door to balloon time between off-hour and regular hour presentation did not significantly change over time. This discrepancy between trends in mortality and door to balloon time may be due to high heterogeneity or may suggest that factors other than door to balloon times contribute to the difference in mortality between off-hours and regular hours. These results should be viewed against secular trends showing decreases in both the absolute mortality rate and door to balloon times,${ }^{72} 73$ and thus call attention to the opportunity to improve quality of care provided during off-hours.

\section{Population impact}

Although the relative odds increase in off-hour mortality seems small, the implications at the population level may be substantial. Assuming a baseline population in-hospital mortality rate of $7 \%$ and 30 day mortality rate of $12 \%$ for acute myocardial infarction, ${ }^{4}{ }^{10}$ the absolute increase in mortality rate during off-hours would be calculated as $0.4 \%$ and $0.6 \%$ respectively from the estimated odds ratio of 1.06. With an estimated 900 000 patients a year presenting to hospitals in the United States with acute myocardial infarction, ${ }^{2}$ and two thirds of them presenting during off-hours, ${ }^{5633}$ annual excess deaths in acute myocardial infarction due to off-hour presentation would be about 2300 for in-hospital deaths and 3800 for deaths within 30 days. In other words, one in 27 in-hospital deaths, or one in 29 deaths within 30 days after admission, would be prevented if the higher mortality during off-hours was resolved.

Alternatively, if we use the estimated odds ratio of 1.03 in the North American region, the excess deaths would be about 1200 for in-hospital deaths and 1900 for deaths within 30 days.

\section{Strengths and limitations}

The strengths of this review include the exhaustive and reproducible search strategy, inclusion of non-English studies, and a large sample size of over a million. If our point estimates for increase in mortality during off-hours is true, one would need a sample size of at least 10000 per group to detect the difference in mortality between off-hours and regular hours with adequate power. Therefore, some past studies may have failed to detect the difference in mortality owing to lack of power. The meta-analysis included studies representing various countries, 
definitions of off-hours, measured time to define off-hour presentation, and mixes of acute myocardial infarction diagnoses. However, the increased mortality in off-hours was fairly robust across subgroups, indicating the consistency of the finding.

This study has certain limitations. The results were derived from observational studies in which patients were not randomized. Therefore, the difference in mortality between off-hours and regular hours may be confounded by patients' clinical characteristics. Although adjustment for mortality outcomes did not explain heterogeneity, inclusion of different confounding variables for adjustment by study may reduce the validity of the finding. Another limitation is high heterogeneity. We anticipated that differences in mortality or door to balloon time between off-hours and regular hours would be heterogeneous by healthcare system, care delivery model of specific institutions, staffing or resource availability, or population demographics included in the study. ${ }^{10} \mathrm{We}$ found that type of acute myocardial infarction and region of study are potential explanations of heterogeneity, but our choice of covariates was determined a priori and was parsimonious to decrease the chances of false positive findings. Different definitions of weekends or nights, types of facility, or mixes of patients may explain some of the unexplained heterogeneity. Therefore, the pooled effect size of this study should be viewed as an average estimate expected across a range of different settings. High heterogeneity also reduces the validity of assessment of publication bias. Although the statistical analyses did not reach significance, publication bias is likely to be present given the visual inspection of the funnel plot. Additionally, potential exists for overlapping of patients in different cohorts. As we were unable to determine quantitatively the extent of overlap, we did sensitivity analyses to exclude such overlapping cohorts. No sensitivity analyses altered our conclusions, lessening the concern about this limitation. Furthermore, the associations reported in this review could be overstated because of the use of odds ratios to estimate the risk of a common event. ${ }^{74}$ Therefore, the overall level of evidence found by this review may be reduced by methodological limitations and heterogeneity. ${ }^{75}$

\section{Conclusions and policy implications}

In conclusion, this meta-analysis suggests that mortality is higher for patients with acute myocardial infarction who present during off-hours compared with regular hours. This finding may be partially attributed to longer door to balloon times during off-hours for patients with ST elevation myocardial infarction. Future studies should explore the variation in the quality of care by time of day, such as number of staff, expertise of staff, and other structural and process attributes in systems of care during off-hours. Performance measures used for value based purchasing, such as the 30 day risk standardized mortality rate, may need to account for differences by time of presentation to a healthcare facility to assess the quality of care. ${ }^{76}$ Efforts to improve systems of care should ensure that comparable outcomes are achieved for patients regardless of the time of day or day of the week that patients present to the healthcare system.

Contributors: AS designed the study; collected, analyzed, and interpreted the data; and drafted and revised the paper. AA designed the study, collected and analyzed the data, and drafted and revised the paper. SRS, KMT, and DAR collected and analyzed the data and revised the paper. LP collected the data and revised the paper. NDS conceptualized and designed the study, interpreted the data, and revised the paper. MHM conceptualized and designed the study, analyzed and interpreted the data, and drafted and revised the paper. HHT conceptualized and designed the study, oversaw and managed the progress, planned analysis and interpreted the data, and drafted and revised the paper. All authors had full access to all of the data in the study and can take responsibility for the integrity of the data and the accuracy of the data analysis. AS is the guarantor.

Funding: Mayo Clinic Division of Cardiovascular Diseases, Mayo Clinic Quality Academy, Mayo Clinic College of Medicine, and Mayo Clinic Center for Science of Healthcare Delivery. Researchers were independent from funders and sponsors, and the study sponsor did not have any influence on the study design; the collection, analysis, and interpretation of data; the writing of the article; or the decision to submit it for publication.

Competing interests: All authors have completed the ICMJE uniform disclosure form at www.icmje.org/coi_disclosure.pdf and declare: no support from any organization for the submitted work other than those listed above; no financial relationships with any organizations that might have an interest in the submitted work in the previous three years; no other relationships or activities that could appear to have influenced the submitted work.

Ethical approval: The study did not require an ethics committee approval. Transparency: The lead author (the manuscript's guarantor) affirms that the manuscript is an honest, accurate, and transparent account of the study being reported; that no important aspects of the study have been omitted; and that any discrepancies from the study as planned (and, if relevant, registered) have been explained.

Data sharing: The dataset is available from the corresponding author at Ting.Henry@mayo.edu.

1 Lozano R, Naghavi M, Foreman K, Lim S, Shibuya K, Aboyans V, et al. Global and regional mortality from 235 causes of death for 20 age groups in 1990 and 2010: a systematic analysis for the Global Burden of Disease Study 2010. Lancet 2012;380:2095-128.

2 Go AS, Mozaffarian D, Roger VL, Benjamin EJ, Berry JD, Borden WB, et al. Heart disease and stroke statistics-2013 update: a report from the American Heart Association. Circulation 2013;127:e6-245.

3 Clarke MS, Wills RA, Bowman RV, Zimmerman PV, Fong KM, Coory MD, et al. Exploratory study of the 'weekend effect' for acute medical admissions to public hospitals in Queensland, Australia. Intern Med J 2010;40:777-83.

4 Kostis WJ, Demissie K, Marcella SW, Shao YH, Wilson AC, Moreyra AE. Weekend versus weekday admission and mortality from myocardial infarction. N Engl J Med 2007;356:1099-109.

5 Kruth P, Zeymer U, Gitt A, Junger C, Wienbergen H, Niedermeier F, et al. Influence of presentation at the weekend on treatment and outcome in ST-elevation myocardial infarction in hospitals with catheterization laboratories. Clin Res Cardiol 2008;97:742-7.

6 Magid DJ, Wang Y, Herrin J, McNamara RL, Bradley EH, Curtis JP, et al. Relationship between time of day, day of week, timeliness of reperfusion, and in-hospital mortality for patients with acute st-segment elevation myocardial infarction. JAMA 2005;294:803-12.

7 Ryan JW, Peterson ED, Chen AY, Roe MT, Ohman EM, Cannon CP, et al. Optimal timing of intervention in non-ST-segment elevation acute coronary syndromes: insights from the CRUSADE Registry. Circulation 2005;112:3049-57.

8 Angus DC, Shorr AF, White A, Dremsizov TT, Schmitz RJ, Kelley MA. Critical care delivery in the United States: distribution of services and compliance with Leapfrog recommendations. Crit Care Med 2006;34:1016-24.

9 Wong HJ, Morra D. Excellent hospital care for all: open and operating 24/7. J Gen Intern Med 2011;26:1050-2.

10 Jneid H, Fonarow GC, Cannon CP, Palacios IF, Kilic T, Moukarbel GV, et al. Impact of time of presentation on the care and outcomes of acute myocardial infarction. Circulation 2008;117:2502-9.

11 Bell CM, Redelmeier DA. Mortality among patients admitted to hospitals on weekends as compared with weekdays. N Engl J Med 2001;345:663-8.

12 Casella G, Ottani F, Ortolani P, Guastaroba P, Santarelli A, Balducelli M, et al. Off-hour primary percutaneous coronary angioplasty does not affect outcome of patients with ST-segment elevation acute myocardial infarction treated within a regional network for reperfusion: the REAL registry. JACC Cardiovasc Interv 2011;4:270-8.

13 Cubeddu RJ, Cruz-Gonzalez I, Kiernan TJ, Truong QA, Rosenfield K, Leinbach RC, et al. ST-elevation myocardial infarction mortality in a major academic center "on-" versus "off-" hours. J Invasive Cardiol 2009;21:518-23.

14 Hong JS, Kang HC, Lee SH. Comparison of case fatality rates for acute myocardial infarction in weekday vs weekend admissions in South Korea. Circ J 2010;74:496-502.

15 Maier B, Behrens S, Graf-Bothe C, Kuckuck H, Roehnisch J-U, Schoeller RG, et al. Time of admission, quality of $\mathrm{PCl}$ care, and outcome of patients with ST-elevation myocardial infarction. Clin Res Cardiol 2010;99:565-72.

16 Sadeghi HM, Grines CL, Chandra HR, Mehran R, Fahy M, Cox DA, et al. Magnitude and impact of treatment delays on weeknights and weekends in patients undergoing primary angioplasty for acute myocardial infarction (the cadillac trial). Am J Cardiol 2004;94:637-40.

17 Moher D, Liberati A, Tetzlaff J, Altman DG. Preferred reporting items for systematic reviews and meta-analyses: the PRISMA statement. J Clin Epidemiol 2009;62:1006-12.

18 Higgins JP, Green S. Cochrane handbook for systematic reviews of interventions version 5.1.0 [updated March 2011]. Cochrane Collaborations, 2011. 


\section{What is already known on this topic}

Past studies suggest that patients with acute myocardial infarction may or may not have higher mortality when they present to hospital during off-hours (weekends and nights) compared with regular hours

No systematic reviews or meta-analyses of this topic have been done

\section{What this study adds}

Patients with acute myocardial infarction presenting during off-hours have higher mortality, and those with ST elevation myocardial infarction have longer door to balloon times

Efforts to improve systems of care should ensure comparable outcomes for patients regardless of time of presentation to hospital

19 Wells G, Shea B, O'Connell D, Peterson J, Welch V, Losos M, et al. The Newcastle-Ottawa Scale (NOS) for assessing the quality of nonrandomised studies in meta-analyses. 3rd Symposium on Systematic Reviews: Beyond the Basics, 2000.

20 Higgins JPT, Thompson SG. Quantifying heterogeneity in a meta-analysis. Stat Med 2002;21:1539-58.

21 Higgins JPT, Thompson SG, Deeks JJ, Altman DG. Measuring inconsistency in meta-analyses. BMJ 2003;327:557-60.

22 DerSimonian R, Laird N. Meta-analysis in clinical trials. Control Clin Trials 1986;7:177-88

23 Duval S, Tweedie R. Trim and fill: a simple funnel-plot-based method of testing and adjusting for publication bias in meta-analysis. Biometrics 2000;56:455-63

24 Begg CB, Mazumdar M. Operating characteristics of a rank correlation test for publication bias. Biometrics 1994:50:1088-101.

25 Abi Rafeh N, Abi-Fadel D, Wetz RV, Khoueiry G, Azab B, Edwards A, et al. A STEMI code protocol improves door-to-balloon time on weekdays and weekends. $J$ Healthc Qual 2009;31:35-43.

26 Ahmar W, Quarin T, Ajani A, Kennedy M, Grigg L. Improvement in door-to-balloon times in management of acute ST-segment elevation myocardial infarction STEMI through the initiation of 'Code AMl'. Intern Med J 2008;38:714-8.

27 Holmes DR, Bell MR, Gersh BJ, Rihal CS, Haro LH, Bjerke CM, et al. Systems of care to improve timeliness of reperfusion therapy for ST-segment elevation myocardial infarction during off hours. JACC Cardiovasc Interv 2008;1:88-96.

28 Khot UN, Johnson ML, Ramsey C, Khot MB, Todd R, Shaikh SR, et al. Emergency department physician activation of the catheterization laboratory and immediate transfer to an immediately available catheterization laboratory reduce door-to-balloon time in ST-elevation myocardial infarction. Circulation 2007;116:67-76.

29 Afolabi BA, Novaro GM, Pinski SL, Fromkin KR, Bush HS. Use of the prehospital ECG improves door-to-balloon times in ST segment elevation myocardial infarction irrespective of time of day or day of week. Emerg Med J 2007;24:588-91.

30 Al Faleh HF, Thalib L, AlHabib KF, Ullah A, AINemer K, AISaif SM, et al. Are acute coronary syndrome patients admitted during off-duty hours treated differently? An analysis of the Saudi Project for Assessment of Acute Coronary Syndrome (SPACE) study. Ann Saudi Med 2012;32:366-71

31 Assali AR, Brosh D, Vaknin-Assa H, Fuchs S, Teplitsky I, Sela O, et al. The impact of circadian variation on outcomes in emergency acute anterior myocardial infarction percutaneous coronary intervention. Catheter Cardiovasc Interv 2006;67:221-6.

32 Aylin P, Yunus A, Bottle A, Majeed A, Bell D. Weekend mortality for emergency admissions: a large, multicentre study. Qual Saf Health Care 2010;19:213-7.

33 Becker D, Soos P, Berta B, Nagy A, Fulop G, Szabo G, et al. Significance of off-hours in centralized primary percutaneous coronary intervention network. Croat Med $J$ 2009;50:476-82.

34 Becker DJ. Do hospitals provide lower quality care on weekends? Health Serv Res 2007;42:1589-612.

35 Beohar N, Chandwaney R, Goodreau LM, Davidson CJ. In-hospital and long-term outcomes of patients with acute myocardial infarction undergoing direct angioplasty during regular and after hours. $J$ Invasive Cardiol 2001;13:669-72.

36 Berger A, Stauffer JC, Radovanovic D, Urban P, Bertel O, Erne P. Comparison of in-hospital mortality for acute myocardial infarction in Switzerland with admission during routine duty hours versus admission during out of hours (insight into the AMIS plus registry). Am J Cardiol 2008;101:422-7.

37 Cardoso CdO, Quadros ASd, Voltolini I, Azmus AD, Cardoso CR, Sebben J, et al. Angioplastia primária no infarto agudo do miocárdio: existe diferença de resultados entre as angioplastias realizadas dentro e fora do horário de rotina? [Portuguese]. Revista Brasileira de Cardiologia Invasiva 2010;18:273-80.

38 Cram P, Hillis SL, Barnett M, Rosenthal GE. Effects of weekend admission and hospital teaching status on in-hospital mortality. Am J Med 2004;117:151-7.

39 Cubeddu RJ, Palacios IF, Blankenship JC, Horvath SA, Xu K, Kovacic JC, et al. Outcome of patients with ST-segment elevation myocardial infarction undergoing primary percutaneous coronary intervention during on- versus off-hours (a Harmonizing Outcomes with Revascularization and Stents in Acute Myocardial Infarction [HORIZONS-AMI] trial substudy). Am J Cardiol 2013;111:946-54.

40 Albuquerque GOd, Szuster E, Corrêa LCT, Goulart E, Souza AC, Sobrinho ALdOA, et al. Análise dos resultados do atendimento ao paciente com infarto agudo do miocárdio com supradesnivelamento do segmento ST nos períodos diurno e noturno [Portuguese]. Revista Brasileira de Cardiologia Invasiva 2009;17:52-7.

41 De Boer SPM, Oemrawsingh RM, Lenzen MJ, van Mieghem NM, Schultz C, Akkerhuis $\mathrm{KM}$, et al. Primary PCl during off-hours is not related to increased mortality. Eur Heart $J$ Acute Cardiovasc Care 2012;1:33-9.

42 Evangelista PA, Barreto SM, Guerra HL. Hospital admission and hospital death associated to ischemic heart diseases at the National Health System (SUS). Arq Bras Cardiol 2008;90:119-26.

43 Garceau P, Dery JP, Lachance P, Grenier S, Rodes-Cabau J, Barbeau G, et al. Treatment delays in patients undergoing primary percutaneous coronary intervention for ST elevation myocardial infarction at the Quebec Heart and Lung Institute. Can J Cardiol 2007:23:53-7B.

44 Glaser R, Naidu SS, Selzer F, Jacobs AK, Laskey WK, Srinivas VS, et al. Factors associated with poorer prognosis for patients undergoing primary percutaneous coronary intervention during off-hours: biology or systems failure? JACC Cardiovasc Interv 2008; $1: 681-8$.

45 Gonzalez MA, Ben-Dor I, Wakabayashi K, Maluenda G, Gaglia MA Jr, Hanna NN, et al. Does on- versus off-hours presentation impact in-hospital outcomes of ST-segment elevation myocardial infarction patients transferred to a tertiary care center? Catheter Cardiovasc Interv 2010;76:484-90.

46 Graham MM, Ghali WA, Southern DA, Traboulsi M, Knudtson ML. Outcomes of after-hours versus regular working hours primary percutaneous coronary intervention for acute myocardial infarction. BMJ Qual Saf 2011;20:60-7.

47 Hansen KW, Hvelplund A, Abildstrom SZ, Prescott E, Madsen M, Madsen JK, et al. Prognosis and treatment in patients admitted with acute myocardial infarction on weekends and weekdays from 1997 to 2009. Int J Cardiol 2013;168:1167-73.

48 Henriques JP, Haasdijk AP, Zijlstra F. Outcome of primary angioplasty for acute myocardial infarction during routine duty hours versus during off-hours. J Am Coll Cardiol 2003;41:2138-42.

49 Horst MA, Stuart JJ, McKinsey N, Gambler AS. Process factors affecting door to percutaneous coronary intervention for acute myocardial infarction patients. Am J Med Qual 2012;27:16-20.

50 Lairez O, Roncalli J, Carrie D, Elbaz M, Galinier M, Tauzin S, et al. Relationship between time of day, day of the week and in-hospital mortality in patients undergoing emergency percutaneous coronary intervention. Arch Cardiovasc Dis 2009;102:811-20.

51 Nakamura M, Yamagishi M, Ueno T, Hara K, Ishiwata S, Itoh T, et al. Current treatment of ST elevation acute myocardial infarction in Japan: door-to-balloon time and total ischemic time from the J-AMI registry. Cardiovasc Interv Ther 2013;28:30-6.

52 Noman A, Ahmed JM, Spyridopoulos I, Bagnall A, Egred M. Mortality outcome of out-of-hours primary percutaneous coronary intervention in the current era. Eur Heart $J$ 2012;33:3046-53.

53 Ortolani P, Marzocchi A, Marrozzini C, Palmerini T, Saia F, Aquilina M, et al. Clinical comparison of "normal-hours" vs "off-hours" percutaneous coronary interventions for ST-elevation myocardial infarction. Am Heart J 2007;154:366-72.

54 Parikh SV, Jacobi JA, Chu E, Addo TA, Warner JJ, Delaney KA, et al. Treatment delay in patients undergoing primary percutaneous coronary intervention for ST-elevation myocardial infarction: a key process analysis of patient and program factors. Am Heart J 2008;155:290-7.

55 Pedersen S, Galatius S, Mogelvang R, Davidsen U, Galloe A, Abildstrom SZ, et al. Long-term prognosis in an ST-segment elevation myocardial infarction population treated with routine primary percutaneous coronary intervention: from clinical trial to real-life experience. Circ Cardiovasc Interv 2009;2:392-400

56 Pollack CV Jr, Hollander JE, Chen AY, Peterson ED, Bangalore S, Peacock FW, et al. Non-ST-elevation myocardial infarction patients who present during off hours have higher risk profiles and are treated less aggressively, but their outcomes are not worse: a report from Can Rapid Risk Stratification of Unstable Angina Patients Suppress ADverse Outcomes with Early Implementation of the ACC/AHA Guidelines CRUSADE initiative. Crit Pathw Cardiol 2009;8:29-33.

57 Rodriguez-Leor O, Fernandez-Nofrerias E, Mauri F, Salvatella N, Carrillo X, Curos A, et al. [Analysis of reperfusion delay in patients with acute myocardial infarction treated with primary angioplasty based on first medical contact and time of presentation] [Spanish]. Rev Esp Cardiol 2011;64:476-83.

58 Siudak Z, Rakowski T, Dziewierz A, Skowronek J, Rutka J, Bagienski M, et al. Primary percutaneous coronary intervention during on- vs off-hours in patients with ST-elevation myocardial infarction: results from EUROTRANSFER registry. Kardiol Pol 2011;69:1017-22.

59 Slonka G, Gasior M, Lekston A, Gierlotka M, Hawranek M, Tajstra M, et al. Comparison of results of percutaneous coronary interventions in patients with ST-segment elevation myocardial infarction during routine working hours or off-hours. Kardiol Pol 2007;65:1171-7.

60 Srimahachota S, Boonyaratavej S, Udayachalerm W, Buddhari W, Chaipromprasit J, Suithichaiyakul T. Comparison of official hours versus non-official hours: percutaneous coronary intervention in acute ST-elevation myocardial infarction patients. J Med Assoc Thai 2007;90:45-51.

61 Uyarel H, Ergelen M, Akkaya E, Ayhan E, Demirci D, Gul M, et al. Impact of day versus night as intervention time on the outcomes of primary angioplasty for acute myocardial infarction. Catheter Cardiovasc Interv 2009;74:826-34.

62 McNamara RL, Wang Y, Herrin J, Curtis JP, Bradley EH, Magid DJ, et al. Effect of door-to-balloon time on mortality in patients with ST-segment elevation myocardial infarction. J Am Coll Cardiol 2006;47:2180-6.

63 Rathore SS, Curtis JP, Chen J, Wang Y, Nallamothu BK, Epstein AJ, et al. Association of door-to-balloon time and mortality in patients admitted to hospital with ST elevation myocardial infarction: national cohort study. BMJ 2009;338:b1807.

64 Pathak EB, Strom JA. Disparities in use of same-day percutaneous coronary intervention for patients with ST-elevation myocardial infarction in Florida, 2001-2005. Am J Cardiol 2008;102:802-8.

65 Grantcharov TP, Bardram L, Peter F-J, Rosenberg J. Laparoscopic performance after one night on call in a surgical department: prospective study. BMJ 2001;323:1222-3.

66 Needleman J, Buerhaus P, Pankratz VS, Leibson CL, Stevens SR, Harris M. Nurse staffing and inpatient hospital mortality. N Engl J Med 2011;364:1037-45

67 Cavallazzi R, Marik PE, Hirani A, Pachinburavan M, Vasu TS, Leiby BE. Association between time of admission to the ICU and mortality: a systematic review and metaanalysis. Chest 2010;138:68-75.

68 Detsky AS, Berwick DM. Teaching physicians to care amid chaos. JAMA 2013;309:987-8

69 Kulkarni VT, Ross JS, Wang Y, Nallamothu BK, Spertus JA, Normand S-LT, et al. Regional density of cardiologists and rates of mortality for acute myocardial infarction and heart failure. Circ Cardiovasc Qual Outcomes 2013;6:352-9. 
70 Ting $\mathrm{HH}$, Bradley EH, Wang Y, Lichtman JH, Nallamothu BK, Sullivan MD, et al. Factors associated with longer time from symptom onset to hospital presentation for patients with ST-elevation myocardial infarction. Arch Intern Med 2008;168:959-68.

71 Ting HH, Chen AY, Roe MT, Chan PS, Spertus JA, Nallamothu BK, et al. Delay from symptom onset to hospital presentation for patients with non-ST-segment elevation myocardial infarction. Arch Intern Med 2010;170:1834-41.

72 Gibson CM, Pride YB, Frederick PD, Pollack CV Jr, Canto JG, Tiefenbrunn AJ, et al. Trends in reperfusion strategies, door-to-needle and door-to-balloon times, and in-hospital mortality among patients with ST-segment elevation myocardial infarction enrolled in the National Registry of Myocardial Infarction from 1990 to 2006. Am Heart J 2008;156:1035-44

73 Krumholz HM, Herrin J, Miller LE, Drye EE, Ling SM, Han LF, et al. Improvements in door-to-balloon time in the United States, 2005 to 2010. Circulation 2011:124:1038-45.

74 Zhang J, Yu KF. What's the relative risk? A method of correcting the odds ratio in cohort studies of common outcomes. JAMA 1998:280:1690-1.
75 Murad MH, Swiglo BA, Sidawy AN, Ascher E, Montori VM. Methodology for clinical practice guidelines for the management of arteriovenous access. J Vasc Surg 2008:48:26-30S. 76 Acute myocardial infarction: hospital 30-day, all-cause, risk-standardized mortality rate (RSMR) following AMI hospitalization. 2012. www.qualitymeasures.ahrq.gov/content. aspx?id=35572.

Accepted: 28 November 2013

Cite this as: BMJ 2014;348:f7393

This is an Open Access article distributed in accordance with the Creative Commons Attribution Non Commercial (CC BY-NC 3.0) license, which permits others to distribute, remix, adapt, build upon this work non-commercially, and license their derivative works on different terms, provided the original work is properly cited and the use is non-commercial. See: http://creativecommons.org/licenses/by-nc/3.0/. 


\section{Tables}

\begin{tabular}{|c|c|c|c|c|c|c|c|}
\hline \multicolumn{8}{|c|}{ Table 1/ Characteristics of eligible cohort studies } \\
\hline $\begin{array}{l}\text { First author, year } \\
\text { (country) }\end{array}$ & $\begin{array}{l}\text { Description of study } \\
\text { participants }\end{array}$ & $\begin{array}{l}\text { Years of } \\
\text { patient } \\
\text { cohort }\end{array}$ & $\begin{array}{l}\text { Measured } \\
\text { time of } \\
\text { presentation }\end{array}$ & $\begin{array}{l}\text { Definition of } \\
\text { off-hours }\end{array}$ & Data source & $\begin{array}{l}\text { Outcomes } \\
\text { assessed }\end{array}$ & Adjusted variables \\
\hline $\begin{array}{l}\text { Abi Rafeh et al, }{ }^{25} \\
2009 \text { (USA) }\end{array}$ & $\begin{array}{l}91 \text { STEMI patients at tertiary } \\
\text { care center in New York }\end{array}$ & $2005-06$ & Procedure & Weekend & $\begin{array}{l}\text { Clinical } \\
\text { registry }\end{array}$ & Door to balloon & - \\
\hline $\begin{array}{l}\text { Afolabi et al, }{ }^{29} 2007 \\
\text { (USA) }\end{array}$ & $\begin{array}{l}167 \text { STEMI patients at } \\
\text { Cleveland Clinic, Florida }\end{array}$ & 2001-04 & Arrival & $\begin{array}{l}\text { Weekend and } \\
\text { night }\end{array}$ & $\begin{array}{l}\text { Clinical } \\
\text { registry }\end{array}$ & Door to balloon & - \\
\hline $\begin{array}{l}\text { Ahmer et al, }{ }^{26} 2008 \\
\text { (Australia) }\end{array}$ & $\begin{array}{l}38 \text { STEMI patients at Royal } \\
\text { Melbourne Hospital }\end{array}$ & 2005 & Arrival & $\begin{array}{l}\text { Weekend and } \\
\text { night }\end{array}$ & $\begin{array}{l}\text { Clinical } \\
\text { registry }\end{array}$ & Door to balloon & - \\
\hline $\begin{array}{l}\text { Al Faleh et al, }{ }^{30} \\
2012 \text { (Saudi Arabia) } \\
\end{array}$ & $\begin{array}{l}1139 \text { STEMI patients from } \\
17 \text { hospitals in SPACE } \\
\text { registry }\end{array}$ & 2005-07 & Admission & $\begin{array}{l}\text { Weekend and } \\
\text { night }\end{array}$ & $\begin{array}{l}\text { Clinical } \\
\text { registry }\end{array}$ & $\begin{array}{l}\text { In-hospital } \\
\text { mortality, door to } \\
\text { balloon }\end{array}$ & - \\
\hline $\begin{array}{l}\text { Assali et al, }{ }^{31} 2006 \\
\text { (Israel) }\end{array}$ & $\begin{array}{l}273 \text { patients with anterior } \\
\text { wall STEMI at Rabin Medical } \\
\text { Center }\end{array}$ & 2001-04 & Admission & Night & $\begin{array}{l}\text { Clinical } \\
\text { registry }\end{array}$ & $\begin{array}{l}\text { In-hospital } \\
\text { mortality, } 30 \text { day } \\
\text { mortality, door to } \\
\text { balloon }\end{array}$ & $\begin{array}{l}\text { Age, left ventricular ejection } \\
\text { fraction, anemia, renal failure, } \\
\text { Killip class, final TIMI flow, } \\
\text { number of coronary vessels } \\
\text { diseased }\end{array}$ \\
\hline $\begin{array}{l}\text { Aylin et al, }{ }^{32} 2010 \\
\text { (England) }\end{array}$ & $\begin{array}{l}68932 \mathrm{AMl} \text { admissions to all } \\
\text { public acute hospitals }\end{array}$ & $2005-06$ & Procedure & Weekend & $\begin{array}{l}\text { Administrative } \\
\text { data }\end{array}$ & $\begin{array}{l}\text { In-hospital } \\
\text { mortality }\end{array}$ & $\begin{array}{l}\text { Age, sex, deprivation, } \\
\text { comorbidities }\end{array}$ \\
\hline $\begin{array}{l}\text { Becker et al, }{ }^{33} 2009 \\
\text { (Hungary) }\end{array}$ & $\begin{array}{l}1890 \text { STEMI patients } \\
\text { admitted to PCI network in } \\
\text { Budapest }\end{array}$ & 2003-05 & Admission & $\begin{array}{l}\text { Weekend and } \\
\text { night }\end{array}$ & $\begin{array}{l}\text { Clinical } \\
\text { registry }\end{array}$ & $\begin{array}{l}30 \text { day mortality, } \\
\text { door to balloon }\end{array}$ & Age, sex \\
\hline $\begin{array}{l}\text { Becker et al, }{ }^{34} 2007 \\
\text { (USA) }\end{array}$ & $\begin{array}{l}922074 \text { Medicare patients } \\
\text { admitted with new diagnosis } \\
\text { of AMI }\end{array}$ & $1989-98$ & Admission & Weekend & $\begin{array}{l}\text { Administrative } \\
\text { data }\end{array}$ & 30 day mortality & - \\
\hline $\begin{array}{l}\text { Bell et al, }{ }^{11} 2001 \\
\text { (Canada) }\end{array}$ & $\begin{array}{l}160220 \text { AMl patients } \\
\text { admitted to hospitals in } \\
\text { Ontario }\end{array}$ & $1988-97$ & Admission & Weekend & $\begin{array}{l}\text { Administrative } \\
\text { data }\end{array}$ & $\begin{array}{l}\text { In-hospital } \\
\text { mortality }\end{array}$ & $\begin{array}{l}\text { Age, sex, Charlson comorbidity } \\
\text { index score }\end{array}$ \\
\hline $\begin{array}{l}\text { Beohar et al, }{ }^{35} 2001 \\
\text { (USA) }\end{array}$ & $\begin{array}{l}220 \text { STEMI patients } \\
\text { undergoing PCI at single } \\
\text { center in Chicago }\end{array}$ & NA & Arrival & $\begin{array}{l}\text { Weekend and } \\
\text { night }\end{array}$ & $\begin{array}{l}\text { Clinical } \\
\text { registry }\end{array}$ & Door to balloon & - \\
\hline $\begin{array}{l}\text { Berger et al }{ }^{36} 2008 \\
\text { (Switzerland) }\end{array}$ & $\begin{array}{l}12480 \text { STEMI patients from } \\
66 \text { hospitals in AMIS registry }\end{array}$ & $1997-2006$ & Admission & $\begin{array}{l}\text { Weekend and } \\
\text { night }\end{array}$ & $\begin{array}{l}\text { Clinical } \\
\text { registry }\end{array}$ & $\begin{array}{l}\text { In-hospital } \\
\text { mortality, door to } \\
\text { balloon }\end{array}$ & $\begin{array}{l}\text { Age, smoking status, } \\
\text { overweight, comorbidities, } \\
\text { Killip's classification at } \\
\text { admission, time from symptom } \\
\text { onset to admission }\end{array}$ \\
\hline $\begin{array}{l}\text { Cardoso et al, }{ }^{37} \\
2010 \text { (Brazil) }\end{array}$ & $\begin{array}{l}112 \text { STEMI patients at single } \\
\text { center in Brazil }\end{array}$ & $2009-10$ & Procedure & Night & $\begin{array}{l}\text { Clinical } \\
\text { registry }\end{array}$ & $\begin{array}{l}\text { In-hospital } \\
\text { mortality, door to } \\
\text { balloon }\end{array}$ & - \\
\hline $\begin{array}{l}\text { Casella et al, }{ }^{12} 2011 \\
\text { (Italy) }\end{array}$ & $\begin{array}{l}3072 \text { STEMI patients in } \\
\text { Italian Region } \\
\text { Emilia-Romagna STEMI } \\
\text { network (REAL registry) }\end{array}$ & 2004-06 & Procedure & $\begin{array}{l}\text { Weekend and } \\
\text { night }\end{array}$ & $\begin{array}{l}\text { Clinical } \\
\text { registry }\end{array}$ & $\begin{array}{l}\text { In-hospital } \\
\text { mortality, door to } \\
\text { balloon }\end{array}$ & $\begin{array}{l}\text { Age, sex, Charlson comorbidity } \\
\text { index score, cardiogenic shock, } \\
\text { inter-hospital transfer for } \\
\text { primary PCl, left ventricular } \\
\text { ejection fraction, multivessel } \\
\text { primary PCI, glycoprotein IIb/llla } \\
\text { inhibitor use, treatment center }\end{array}$ \\
\hline $\begin{array}{l}\text { Clarke et al, }{ }^{3} 2010 \\
\text { (Australia) }\end{array}$ & $\begin{array}{l}17910 \text { AMI patients in } \\
\text { Queensland database }\end{array}$ & $2002-06$ & Admission & Weekend & $\begin{array}{l}\text { Administrative } \\
\text { data }\end{array}$ & $\begin{array}{l}\text { In-hospital } \\
\text { mortality, } 30 \text { day } \\
\text { mortality }\end{array}$ & $\begin{array}{l}\text { Age, sex, indigenous status, } \\
\text { remote residence, } \\
\text { socioeconomic status, } \\
\text { comorbidities }\end{array}$ \\
\hline $\begin{array}{l}\text { Cram et al, }{ }^{38} 2004 \\
\text { (USA) }\end{array}$ & $\begin{array}{l}42974 \text { AMI patients admitted } \\
\text { to hospitals in California }\end{array}$ & 1998 & Admission & Weekend & $\begin{array}{l}\text { Administrative } \\
\text { data }\end{array}$ & $\begin{array}{l}\text { In-hospital } \\
\text { mortality }\end{array}$ & Age, sex, race, comorbidities \\
\hline $\begin{array}{l}\text { Cubeddu et al, }{ }^{39} \\
2013 \text { (multinational) }\end{array}$ & $\begin{array}{l}2440 \text { STEMI patients who } \\
\text { underwent primary PCI in } \\
\text { HORIZONS-AMI trial }\end{array}$ & $2005-07$ & Arrival & $\begin{array}{l}\text { Weekend and } \\
\text { night }\end{array}$ & $\begin{array}{l}\text { Clinical } \\
\text { registry }\end{array}$ & $\begin{array}{l}\text { In-hospital } \\
\text { mortality, door to } \\
\text { balloon }\end{array}$ & $\begin{array}{l}\text { Age, sex, Killip class, baseline } \\
\text { TIMI flow, creatinine, } \\
\text { hemoglobin, left ventricular } \\
\text { ejection fraction, randomization } \\
\text { to bivalirudin, smoking history, } \\
\text { diabetes mellitus, door to } \\
\text { balloon time, total ischemic } \\
\text { time, affected coronary vessel, } \\
\text { clopidogrel use }\end{array}$ \\
\hline
\end{tabular}


Table 1 (continued)

\begin{tabular}{|c|c|c|c|c|c|c|c|}
\hline $\begin{array}{l}\text { First author, year } \\
\text { (country) }\end{array}$ & $\begin{array}{l}\text { Description of study } \\
\text { participants }\end{array}$ & $\begin{array}{l}\text { Years of } \\
\text { patient } \\
\text { cohort }\end{array}$ & $\begin{array}{l}\text { Measured } \\
\text { time of } \\
\text { presentation }\end{array}$ & $\begin{array}{l}\text { Definition of } \\
\text { off-hours }\end{array}$ & Data source & $\begin{array}{l}\text { Outcomes } \\
\text { assessed }\end{array}$ & Adjusted variables \\
\hline $\begin{array}{l}\text { Cubeddu et al, }{ }^{13} \\
2009 \text { (USA) }\end{array}$ & $\begin{array}{l}747 \text { STEMI patients admitted } \\
\text { to Massachusetts General } \\
\text { Hospital for primary PCI }\end{array}$ & 2003-07 & Admission & $\begin{array}{l}\text { Weekend and } \\
\text { night }\end{array}$ & $\begin{array}{l}\text { Clinical } \\
\text { registry }\end{array}$ & $\begin{array}{l}\text { In-hospital } \\
\text { mortality, door to } \\
\text { balloon }\end{array}$ & $\begin{array}{l}\text { Age, body surface area, sex, } \\
\text { family history of coronary artery } \\
\text { disease, smoking, } \\
\text { comorbidities, serum creatinine }\end{array}$ \\
\hline $\begin{array}{l}\text { De Albuquerque et } \\
\text { al, }{ }^{40} 2009 \text { (Brazil) }\end{array}$ & $\begin{array}{l}274 \text { STEMI patients admitted } \\
\text { to single center in Brazil }\end{array}$ & 2004-08 & Procedure & $\begin{array}{l}\text { Weekend and } \\
\text { night }\end{array}$ & $\begin{array}{l}\text { Clinical } \\
\text { registry }\end{array}$ & $\begin{array}{l}\text { In-hospital } \\
\text { mortality }\end{array}$ & - \\
\hline $\begin{array}{l}\text { De Boer et al, }{ }^{41} \\
2012 \text { (Netherland) }\end{array}$ & $\begin{array}{l}4352 \text { STEMI patients who } \\
\text { underwent primary } \mathrm{PCI} \text { at } \\
\text { single institution }\end{array}$ & $2000-09$ & Procedure & $\begin{array}{l}\text { Weekend and } \\
\text { night }\end{array}$ & $\begin{array}{l}\text { Clinical } \\
\text { registry }\end{array}$ & 30 day mortality & $\begin{array}{l}\text { Age, sex, comorbidities, shock, } \\
\text { multivessel disease }\end{array}$ \\
\hline $\begin{array}{l}\text { Evangelista et al, }{ }^{42} \\
2008 \text { (Brazil) }\end{array}$ & $\begin{array}{l}869 \text { patients with suspected } \\
\text { AMI admitted to public and } \\
\text { private hospitals }\end{array}$ & 2002 & Admission & Weekend & $\begin{array}{l}\text { Administrative } \\
\text { data }\end{array}$ & $\begin{array}{l}\text { In-hospital } \\
\text { mortality }\end{array}$ & $\begin{array}{l}\text { Age, sex, admission specialty, } \\
\text { intensive care unit admission, } \\
\text { hospital type, direct admission }\end{array}$ \\
\hline $\begin{array}{l}\text { Garceau et al, }{ }^{43} \\
2007 \text { (Canada) }\end{array}$ & $\begin{array}{l}69 \text { STEMI patients directly } \\
\text { admitted to Quebec Heart } \\
\text { and Lung Institute }\end{array}$ & 2004-05 & Arrival & $\begin{array}{l}\text { Weekend and } \\
\text { night }\end{array}$ & $\begin{array}{l}\text { Clinical } \\
\text { registry }\end{array}$ & Door to balloon & - \\
\hline $\begin{array}{l}\text { Glaser et al, }{ }^{44} 2008 \\
\text { (USA) }\end{array}$ & $\begin{array}{l}685 \text { STEMI patients in } \\
\text { national Heart, Lung, and } \\
\text { Blood Institute Dynamic } \\
\text { Registry }\end{array}$ & $1997-2006$ & Procedure & Night & $\begin{array}{l}\text { Clinical } \\
\text { registry }\end{array}$ & $\begin{array}{l}\text { In-hospital } \\
\text { mortality }\end{array}$ & $\begin{array}{l}\text { Age, comorbidities, cardiogenic } \\
\text { shock, characteristics of } \\
\text { affected and treated coronary } \\
\text { vessels }\end{array}$ \\
\hline $\begin{array}{l}\text { Gonzalez et al, }{ }^{45} \\
2010 \text { (USA) }\end{array}$ & $\begin{array}{l}786 \text { STEMI patients } \\
\text { transferred to single } \\
\text { institution }\end{array}$ & 2006-09 & Arrival & $\begin{array}{l}\text { Weekend and } \\
\text { night }\end{array}$ & $\begin{array}{l}\text { Clinical } \\
\text { registry }\end{array}$ & $\begin{array}{l}\text { In-hospital } \\
\text { mortality }\end{array}$ & - \\
\hline $\begin{array}{l}\text { Graham et al, }{ }^{46} \\
2011 \text { (Canada) }\end{array}$ & $\begin{array}{l}1664 \text { STEMI patients from } \\
\text { APPROACH registry in } \\
\text { Alberta }\end{array}$ & $1999-2006$ & Procedure & $\begin{array}{l}\text { Weekend and } \\
\text { night }\end{array}$ & $\begin{array}{l}\text { Clinical } \\
\text { registry }\end{array}$ & $\begin{array}{l}30 \text { day mortality, } \\
\text { door to balloon }\end{array}$ & $\begin{array}{l}\text { Age, sex, left ventricular ejection } \\
\text { fraction, comorbidities, number } \\
\text { of affected coronary vessels, } \\
\text { intervened coronary vessels, } \\
\text { glycoprotein Ilb/llla inhibitor, } \\
\text { stent, intra-aortic balloon pump, } \\
\text { inotrope use }\end{array}$ \\
\hline $\begin{array}{l}\text { Hansen et al, }{ }^{47} 2012 \\
\text { (Denmark) }\end{array}$ & $\begin{array}{l}92169 \text { AMI patients in } \\
\text { Danish National Patient } \\
\text { Registry }\end{array}$ & $1997-2009$ & Admission & Weekend & $\begin{array}{l}\text { Administrative } \\
\text { data }\end{array}$ & $\begin{array}{l}\text { In-hospital } \\
\text { mortality, } 30 \text { day } \\
\text { mortality }\end{array}$ & Age, sex, comorbidities \\
\hline $\begin{array}{l}\text { Henriques et al, }{ }^{48} \\
2003 \text { (Netherlands) }\end{array}$ & $\begin{array}{l}1702 \text { STEMI patients who } \\
\text { underwent } \mathrm{PCl} \text { at single } \\
\text { institution }\end{array}$ & $1994-2000$ & Admission & Night & $\begin{array}{l}\text { Clinical } \\
\text { registry }\end{array}$ & $\begin{array}{l}30 \text { day mortality, } \\
\text { door to balloon }\end{array}$ & - \\
\hline $\begin{array}{l}\text { Holmes et al, }{ }^{27} 2008 \\
\text { (USA) }\end{array}$ & $\begin{array}{l}60 \text { STEMI patients presented } \\
\text { to Mayo Clinic Rochester }\end{array}$ & 2003 & Arrival & $\begin{array}{l}\text { Weekend and } \\
\text { night }\end{array}$ & $\begin{array}{l}\text { Clinical } \\
\text { registry }\end{array}$ & Door to balloon & - \\
\hline $\begin{array}{l}\text { Hong et al, }{ }^{14} 2010 \\
\text { (South Korea) }\end{array}$ & $\begin{array}{l}97466 \text { AMI patients admitted } \\
\text { to hospitals in South Korea }\end{array}$ & 2003-07 & Admission & Weekend & $\begin{array}{l}\text { Administrative } \\
\text { data }\end{array}$ & 30 day mortality & $\begin{array}{l}\text { Age, sex, comorbidities, length } \\
\text { of stay, complications }\end{array}$ \\
\hline $\begin{array}{l}\text { Horst et al, }{ }^{49} 2012 \\
\text { (USA) }\end{array}$ & $\begin{array}{l}268 \text { STEMI patients who } \\
\text { underwent } \mathrm{PCl} \text { at single } \\
\text { community hospital in } \\
\text { Pennsylvania }\end{array}$ & $2006-07$ & Arrival & $\begin{array}{l}\text { Weekend and } \\
\text { night }\end{array}$ & $\begin{array}{l}\text { Administrative } \\
\text { data }\end{array}$ & Door to balloon & $\begin{array}{l}\text { Mode of presentation, } \\
\text { pre-notification, chest pain, } \\
\text { portable radiograph, cardiology } \\
\text { group }\end{array}$ \\
\hline $\begin{array}{l}\text { Jneid et al, }{ }^{10} 2008 \\
\text { (USA) }\end{array}$ & $\begin{array}{l}62814 \text { AMI patients in } \\
\text { GWTG-CAD national } \\
\text { database }\end{array}$ & $2000-05$ & Arrival & $\begin{array}{l}\text { Weekend and } \\
\text { night }\end{array}$ & $\begin{array}{l}\text { Clinical } \\
\text { registry }\end{array}$ & $\begin{array}{l}\text { In-hospital } \\
\text { mortality, door to } \\
\text { balloon }\end{array}$ & $\begin{array}{l}\text { Age, sex, race, body mass } \\
\text { index, insurance type, systolic } \\
\text { blood pressure, cardiac } \\
\text { diagnosis, ST elevation or left } \\
\text { bundle branch block, } \\
\text { comorbidities }\end{array}$ \\
\hline $\begin{array}{l}\text { Khot et al, }{ }^{28} 2007 \\
\text { (USA) }\end{array}$ & $\begin{array}{l}60 \text { STEMI patients at tertiary } \\
\text { care center in Indiana }\end{array}$ & 2004-05 & Arrival & $\begin{array}{l}\text { Weekend and } \\
\text { night }\end{array}$ & $\begin{array}{l}\text { Clinical } \\
\text { registry }\end{array}$ & Door to balloon & - \\
\hline $\begin{array}{l}\text { Kostis et al, }{ }^{4} 2007 \\
\text { (USA) }\end{array}$ & $\begin{array}{l}231164 \text { AMI patients } \\
\text { admitted to New Jersey } \\
\text { hospitals in MIDAS database }\end{array}$ & $1987-2002$ & Admission & Weekend & $\begin{array}{l}\text { Administrative } \\
\text { data }\end{array}$ & $\begin{array}{l}\text { In-hospital } \\
\text { mortality, } 30 \text { day } \\
\text { mortality }\end{array}$ & $\begin{array}{l}\text { Age, sex, site of myocardial } \\
\text { infarction, comorbidities }\end{array}$ \\
\hline $\begin{array}{l}\text { Kruth et al, }{ }^{5} 2008 \\
\text { (Germany) }\end{array}$ & $\begin{array}{l}11516 \text { STEMI patients from } \\
131 \text { hospitals in } \\
\text { MITRA-PLUS registry }\end{array}$ & 1994-2002 & Admission & $\begin{array}{l}\text { Weekend and } \\
\text { night }\end{array}$ & $\begin{array}{l}\text { Clinical } \\
\text { registry }\end{array}$ & $\begin{array}{l}\text { In-hospital } \\
\text { mortality, door to } \\
\text { balloon }\end{array}$ & $\begin{array}{l}\text { Age, sex, comorbidities, } \\
\text { pre-hospital delay, tachycardia }\end{array}$ \\
\hline
\end{tabular}


Table 1 (continued)

\begin{tabular}{|c|c|c|c|c|c|c|c|}
\hline $\begin{array}{l}\text { First author, year } \\
\text { (country) }\end{array}$ & $\begin{array}{l}\text { Description of study } \\
\text { participants }\end{array}$ & $\begin{array}{l}\text { Years of } \\
\text { patient } \\
\text { cohort }\end{array}$ & $\begin{array}{l}\text { Measured } \\
\text { time of } \\
\text { presentation }\end{array}$ & $\begin{array}{l}\text { Definition of } \\
\text { off-hours }\end{array}$ & Data source & $\begin{array}{l}\text { Outcomes } \\
\text { assessed }\end{array}$ & Adjusted variables \\
\hline $\begin{array}{l}\text { Lairez et al, },^{50} 2009 \\
\text { (France) }\end{array}$ & $\begin{array}{l}2266 \text { AMI patients } \\
\text { undergoing emergency } \mathrm{PCl} \\
\text { at single institution }\end{array}$ & 2005-08 & Procedure & $\begin{array}{l}\text { Weekend and } \\
\text { night }\end{array}$ & $\begin{array}{l}\text { Clinical } \\
\text { registry }\end{array}$ & $\begin{array}{l}\text { In-hospital } \\
\text { mortality }\end{array}$ & $\begin{array}{l}\text { Age, sex, year of procedure, } \\
\text { history of myocardial infarction } \\
\text { and coronary angioplasty, } \\
\text { number of affected and treated } \\
\text { vessels }\end{array}$ \\
\hline $\begin{array}{l}\text { Magid et al, }{ }^{6} 2005 \\
\text { (USA) }\end{array}$ & $\begin{array}{l}102086 \text { STEMI patients in } \\
\text { NMRI registry }\end{array}$ & 1999-2002 & Arrival & $\begin{array}{l}\text { Weekend and } \\
\text { night }\end{array}$ & $\begin{array}{l}\text { Clinical } \\
\text { registry }\end{array}$ & $\begin{array}{l}\text { In-hospital } \\
\text { mortality, door to } \\
\text { balloon }\end{array}$ & $\begin{array}{l}\text { Age, sex, race, insurance } \\
\text { status, smoking status, family } \\
\text { history of coronary artery } \\
\text { disease, comorbidities }\end{array}$ \\
\hline $\begin{array}{l}\text { Maier et al, }{ }^{15} 2010 \\
\text { (Berlin) }\end{array}$ & $\begin{array}{l}2131 \text { STEMI patients in } \\
\text { Merlin Myocardial Infarction } \\
\text { Registry }\end{array}$ & 2004-07 & Admission & $\begin{array}{l}\text { Weekend and } \\
\text { night }\end{array}$ & $\begin{array}{l}\text { Clinical } \\
\text { registry }\end{array}$ & $\begin{array}{l}\text { In-hospital } \\
\text { mortality, door to } \\
\text { balloon }\end{array}$ & $\begin{array}{l}\text { Age, sex, cardiogenic shock on } \\
\text { admission, comorbidities, } \\
\text { prolonged door to balloon time, } \\
\text { treatment by physician escorted } \\
\text { EMS }\end{array}$ \\
\hline $\begin{array}{l}\text { Nakamura et al, }{ }^{51} \\
2013 \text { (Japan) }\end{array}$ & $\begin{array}{l}1974 \text { STEMI patients in } \\
\text { Japan Acute Myocardial } \\
\text { Infarction registry }\end{array}$ & 2011 & Procedure & $\begin{array}{l}\text { Weekend and } \\
\text { night }\end{array}$ & $\begin{array}{l}\text { Clinical } \\
\text { registry }\end{array}$ & Door to balloon & - \\
\hline $\begin{array}{l}\text { Noman et al, }{ }^{52} 2012 \\
\text { (UK) }\end{array}$ & $\begin{array}{l}2571 \text { STEMI patients } \\
\text { undergoing primary } \mathrm{PCl} \text { at } \\
\text { single center }\end{array}$ & $2008-11$ & Procedure & $\begin{array}{l}\text { Weekend and } \\
\text { night }\end{array}$ & $\begin{array}{l}\text { Clinical } \\
\text { registry }\end{array}$ & $\begin{array}{l}\text { In-hospital } \\
\text { mortality, door to } \\
\text { balloon }\end{array}$ & $\begin{array}{l}\text { Age, sex, admission systolic } \\
\text { blood pressure, admission heart } \\
\text { rate, total ischemic time, } \\
\text { admission creatinine and } \\
\text { hemoglobin, diabetes, previous } \\
\text { CABG, anterior myocardial } \\
\text { infarction, multivessel disease }\end{array}$ \\
\hline $\begin{array}{l}\text { Ortolani et al, }{ }^{53} 2007 \\
\text { (Italy) }\end{array}$ & $\begin{array}{l}985 \text { STEMI patients in } \\
\text { Bologna PPCI STEMI } \\
\text { registry }\end{array}$ & $2003-05$ & Procedure & $\begin{array}{l}\text { Weekend and } \\
\text { night }\end{array}$ & $\begin{array}{l}\text { Clinical } \\
\text { registry }\end{array}$ & $\begin{array}{l}\text { In-hospital } \\
\text { mortality, door to } \\
\text { balloon }\end{array}$ & $\begin{array}{l}\text { Age, sex, prolonged ECG to } \\
\text { balloon time, left ventricular } \\
\text { ejection fraction, cardiogenic } \\
\text { shock, multivessel disease, } \\
\text { glycoprotein Ilb/Illa use, final } \\
\text { TIMI flow }\end{array}$ \\
\hline $\begin{array}{l}\text { Parikh et al, }{ }^{54} 2008 \\
\text { (USA) }\end{array}$ & $\begin{array}{l}184 \text { STEMI patients } \\
\text { presenting to single center }\end{array}$ & $2000-06$ & Arrival & $\begin{array}{l}\text { Weekend and } \\
\text { night }\end{array}$ & $\begin{array}{l}\text { Clinical } \\
\text { registry }\end{array}$ & Door to balloon & $\begin{array}{l}\text { Language, previous stroke, } \\
\text { cardiogenic shock }\end{array}$ \\
\hline $\begin{array}{l}\text { Pedersen et al, }{ }^{55} \\
2009 \text { (Denmark) }\end{array}$ & $\begin{array}{l}847 \text { STEMI patients admitted } \\
\text { to two hospitals in Denmark }\end{array}$ & 2004 & Arrival & $\begin{array}{l}\text { Weekend and } \\
\text { night }\end{array}$ & $\begin{array}{l}\text { Clinical } \\
\text { registry }\end{array}$ & Door to balloon & $\begin{array}{l}\text { Age, sex, admission to invasive } \\
\text { centers, smoking status, } \\
\text { comorbidities, characteristics of } \\
\text { affected coronary vessel, } \\
\text { glycoprotein Ilb/llla use, drug } \\
\text { eluting stent use }\end{array}$ \\
\hline $\begin{array}{l}\text { Pollack et al, }{ }^{56} 2009 \\
\text { (USA) }\end{array}$ & $\begin{array}{l}34297 \text { NSTEMI patients in } \\
\text { CRUSADE registry }\end{array}$ & 2001-03 & Arrival & $\begin{array}{l}\text { Weekend and } \\
\text { night }\end{array}$ & $\begin{array}{l}\text { Clinical } \\
\text { registry }\end{array}$ & $\begin{array}{l}\text { In-hospital } \\
\text { mortality }\end{array}$ & $\begin{array}{l}\text { Age, sex, race, body mass } \\
\text { index, insurance status, } \\
\text { smoking status, family history } \\
\text { of coronary artery disease, } \\
\text { comorbidities, ischemic ST } \\
\text { changes, signs of heart failure, } \\
\text { heart rate, systolic blood } \\
\text { pressure at presentation, } \\
\text { cardiologist care, number of } \\
\text { hospital beds and region, } \\
\text { teaching status, interventional } \\
\text { capability }\end{array}$ \\
\hline $\begin{array}{l}\text { Rodriguez-Leor et } \\
\text { al, }{ }^{57} 2011 \text { (Spain) }\end{array}$ & $\begin{array}{l}457 \text { STEMI patients at single } \\
\text { center }\end{array}$ & 2007-09 & Procedure & $\begin{array}{l}\text { Weekend and } \\
\text { night }\end{array}$ & $\begin{array}{l}\text { Clinical } \\
\text { registry }\end{array}$ & Door to balloon & - \\
\hline $\begin{array}{l}\text { Sadeghi et al, }{ }^{16} \\
2004 \text { (USA) }\end{array}$ & $\begin{array}{l}2036 \text { STEMI patients who } \\
\text { underwent PCI in CADILLAC } \\
\text { trial }\end{array}$ & 1997-99 & Arrival & $\begin{array}{l}\text { Weekend and } \\
\text { night }\end{array}$ & $\begin{array}{l}\text { Clinical } \\
\text { registry }\end{array}$ & $\begin{array}{l}30 \text { day mortality, } \\
\text { door to balloon }\end{array}$ & $\begin{array}{l}\text { Sex, comorbidities, left } \\
\text { ventricular ejection fraction, } \\
\text { affected coronary vessel }\end{array}$ \\
\hline $\begin{array}{l}\text { Siudak et al, }{ }^{58} 2011 \\
\text { (European } \\
\text { countries) }\end{array}$ & $\begin{array}{l}1650 \text { STEMI patients in } \\
\text { EUROTRANSFER Registry }\end{array}$ & 2005-07 & Procedure & $\begin{array}{l}\text { Weekend and } \\
\text { night }\end{array}$ & $\begin{array}{l}\text { Clinical } \\
\text { registry }\end{array}$ & $\begin{array}{l}\text { In-hospital } \\
\text { mortality, } 30 \text { day } \\
\text { mortality }\end{array}$ & - \\
\hline $\begin{array}{l}\text { Slonka et al, }{ }^{59} 2007 \\
\text { (Poland) }\end{array}$ & $\begin{array}{l}1778 \text { STEMI patients at } \\
\text { single center }\end{array}$ & $1998-2003$ & Admission & $\begin{array}{l}\text { Weekend and } \\
\text { night }\end{array}$ & $\begin{array}{l}\text { Clinical } \\
\text { registry }\end{array}$ & $\begin{array}{l}\text { In-hospital } \\
\text { mortality }\end{array}$ & - \\
\hline $\begin{array}{l}\text { Srimahachota et } \\
\text { al, }{ }^{60} 2007 \text { (Thailand) }\end{array}$ & $\begin{array}{l}256 \text { STEMI patients at King } \\
\text { Chulalongkorn Memorial } \\
\text { Hospital }\end{array}$ & $1999-2003$ & Procedure & $\begin{array}{l}\text { Weekend and } \\
\text { night }\end{array}$ & $\begin{array}{l}\text { Clinical } \\
\text { registry }\end{array}$ & $\begin{array}{l}\text { In-hospital } \\
\text { mortality, door to } \\
\text { balloon }\end{array}$ & $\begin{array}{l}\text { Sex, hypertension, dyslipidemia, } \\
\text { cardiogenic shock, angiographic } \\
\text { success }\end{array}$ \\
\hline
\end{tabular}


Table 1 (continued)

\begin{tabular}{|c|c|c|c|c|c|c|c|}
\hline $\begin{array}{l}\text { First author, year } \\
\text { (country) }\end{array}$ & $\begin{array}{l}\text { Description of study } \\
\text { participants }\end{array}$ & $\begin{array}{l}\text { Years of } \\
\text { patient } \\
\text { cohort }\end{array}$ & $\begin{array}{l}\text { Measured } \\
\text { time of } \\
\text { presentation }\end{array}$ & $\begin{array}{l}\text { Definition of } \\
\text { off-hours }\end{array}$ & Data source & $\begin{array}{l}\text { Outcomes } \\
\text { assessed }\end{array}$ & Adjusted variables \\
\hline $\begin{array}{l}\text { Uyarel et al, }{ }^{61} 2009 \\
\text { (Turkey) }\end{array}$ & $\begin{array}{l}2644 \text { STEMI patients } \\
\text { presenting to single center }\end{array}$ & 2003-08 & Procedure & Night & $\begin{array}{l}\text { Clinical } \\
\text { registry }\end{array}$ & $\begin{array}{l}\text { In-hospital } \\
\text { mortality, door to } \\
\text { balloon }\end{array}$ & $\begin{array}{l}\text { Age, sex, comorbidities, } \\
\text { admission cardiogenic shock, } \\
\text { admission hyperglycemia, left } \\
\text { ventricular ejection fraction, } \\
\text { infarction site, reperfusion time, } \\
\text { procedural characteristics }\end{array}$ \\
\hline
\end{tabular}

$\mathrm{AMI}=$ acute myocardial infarction; $\mathrm{CABG}=$ coronary artery bypass graft; $\mathrm{ECG}=$ electrocardiography; $\mathrm{EMS}=$ emergency medical services; $\mathrm{PCl}=$ percutaneous coronary intervention; STEMI=ST elevation myocardial infarction; TIMI=Thrombolysis in Myocardial Infarction. 
Table 2/ Subgroup analyses for odds ratio of in-hospital or $\mathbf{3 0}$ day mortality due to acute myocardial infarction during off-hours compared with regular hours

\begin{tabular}{|c|c|c|c|c|}
\hline Subgroup & No of cohorts & Odds ratio $(95 \% \mathrm{Cl})$ & $I^{2}(\%)$ & $P$ value for interaction \\
\hline \multicolumn{5}{|l|}{ Diagnosis*: } \\
\hline STEMI & 25 & $1.12(1.03$ to 1.22$)$ & 42 & \multirow[t]{2}{*}{$<0.01$} \\
\hline Non-STEMI & 2 & 0.96 (0.91 to 1.02$)$ & 0 & \\
\hline \multicolumn{5}{|l|}{ Type of off-hours: } \\
\hline Weekend and night & 22 & 1.09 (1.00 to 1.18$)$ & 57 & \multirow[t]{3}{*}{0.25} \\
\hline Weekend & 16 & 1.06 (1.03 to 1.09$)$ & 85 & \\
\hline Night & 4 & 1.88 (0.93 to 3.80$)$ & 70 & \\
\hline \multicolumn{5}{|c|}{ Measured time of presentation: } \\
\hline Arrival & 6 & $1.02(0.93$ to 1.10$)$ & 56 & \multirow[t]{3}{*}{0.27} \\
\hline Admission & 24 & $1.07(1.04$ to 1.10$)$ & 82 & \\
\hline Start of $\mathrm{PCl}$ & 12 & $1.20(0.97$ to 1.47$)$ & 47 & \\
\hline \multicolumn{5}{|l|}{ Data source: } \\
\hline Clinical registry & 27 & 1.11 (1.02 to 1.21$)$ & 58 & \multirow[t]{2}{*}{0.29} \\
\hline Administrative data & 15 & 1.06 (1.03 to 1.09$)$ & 86 & \\
\hline \multicolumn{5}{|l|}{ Regiont: } \\
\hline North America & 15 & 1.03 (1.01 to 1.04$)$ & 49 & \multirow[t]{3}{*}{$<0.01$} \\
\hline Europe & 18 & 1.08 (1.02 to 1.15$)$ & 53 & \\
\hline Others & 8 & $1.25(1.15$ to 1.36$)$ & 15 & \\
\hline \multicolumn{5}{|l|}{ Outcome adjustment: } \\
\hline Adjusted & 30 & $1.07(1.04$ to 1.10$)$ & 75 & \multirow[t]{2}{*}{0.28} \\
\hline Unadjusted & 12 & $1.19(0.98$ to 1.44$)$ & 48 & \\
\hline
\end{tabular}

$\mathrm{PCl}=$ percutaneous coronary intervention; STEMI=ST elevation myocardial infarction.

*One study reported results by two different diagnosis groups (STEMI and non-STEMI).

†One study reported outcome from 11 countries across continents. 
Table 3| Overall and subgroup analyses for mean difference of door to balloon times for STEMI patients during off-hours compared with regular hours

\begin{tabular}{|c|c|c|c|c|}
\hline Subgroup & No of cohorts & Mean difference $(95 \% \mathrm{Cl})$ in minutes & $I^{2}(\%)$ & $P$ value for interaction \\
\hline All studies & 29 & $14.8(10.7$ to 19.0$)$ & 99 & \\
\hline \multicolumn{5}{|l|}{ Type of off-hours*: } \\
\hline Weekend and night & 21 & $15.8(10.5$ to 21.0$)$ & 99 & \multirow[t]{3}{*}{0.37} \\
\hline Weekend & 3 & 17.8 (9.0 to 26.6$)$ & 70 & \\
\hline Night & 7 & $10.6(3.7$ to 17.4$)$ & 93 & \\
\hline \multicolumn{5}{|c|}{ Measured time of presentation: } \\
\hline Arrival & 12 & 20.0 (16.1 to 23.8$)$ & 98 & \multirow[t]{3}{*}{$<0.01$} \\
\hline Admission & 8 & $12.3(4.5$ to 20.1$)$ & 83 & \\
\hline Start of $\mathrm{PCl}$ & 9 & $7.1(3.2$ to 11.0$)$ & 92 & \\
\hline \multicolumn{5}{|l|}{ Regiont: } \\
\hline North America & 12 & 20.8 (16.5 to 25.0$)$ & 83 & \multirow[t]{3}{*}{$<0.01$} \\
\hline Europe & 11 & $7.2(3.6$ to 10.9$)$ & 97 & \\
\hline Others & 5 & 21.3 (4.4 to 38.2$)$ & 89 & \\
\hline
\end{tabular}

$\mathrm{PCl}=$ percutaneous coronary intervention; STEMI=ST elevation myocardial infarction.

*Two studies reported results for weekend presentations as subgroup analysis. ${ }^{49} 50$

†One study reported outcome from 11 countries across continents. ${ }^{39}$ 


\section{Figures}

Articles identified through literature search $(n=487)$

$\rightarrow$ Articles excluded on basis of initial abstract review $(n=322)$

Articles manually added $(n=4)$

Full text articles reviewed $(n=169)$

Excluded $(n=121)$ :

Non-original studies $(n=20)$

Not about acute myocardial infarction $(n=44)$

Did not measure effects of time of presentation $(n=21)$

No outcomes of interest reported $(n=16)$

Duplicate reports $(n=20)$

Studies included in analysis $(n=48)$

Fig 1 Flow chart for selection of eligible studies 


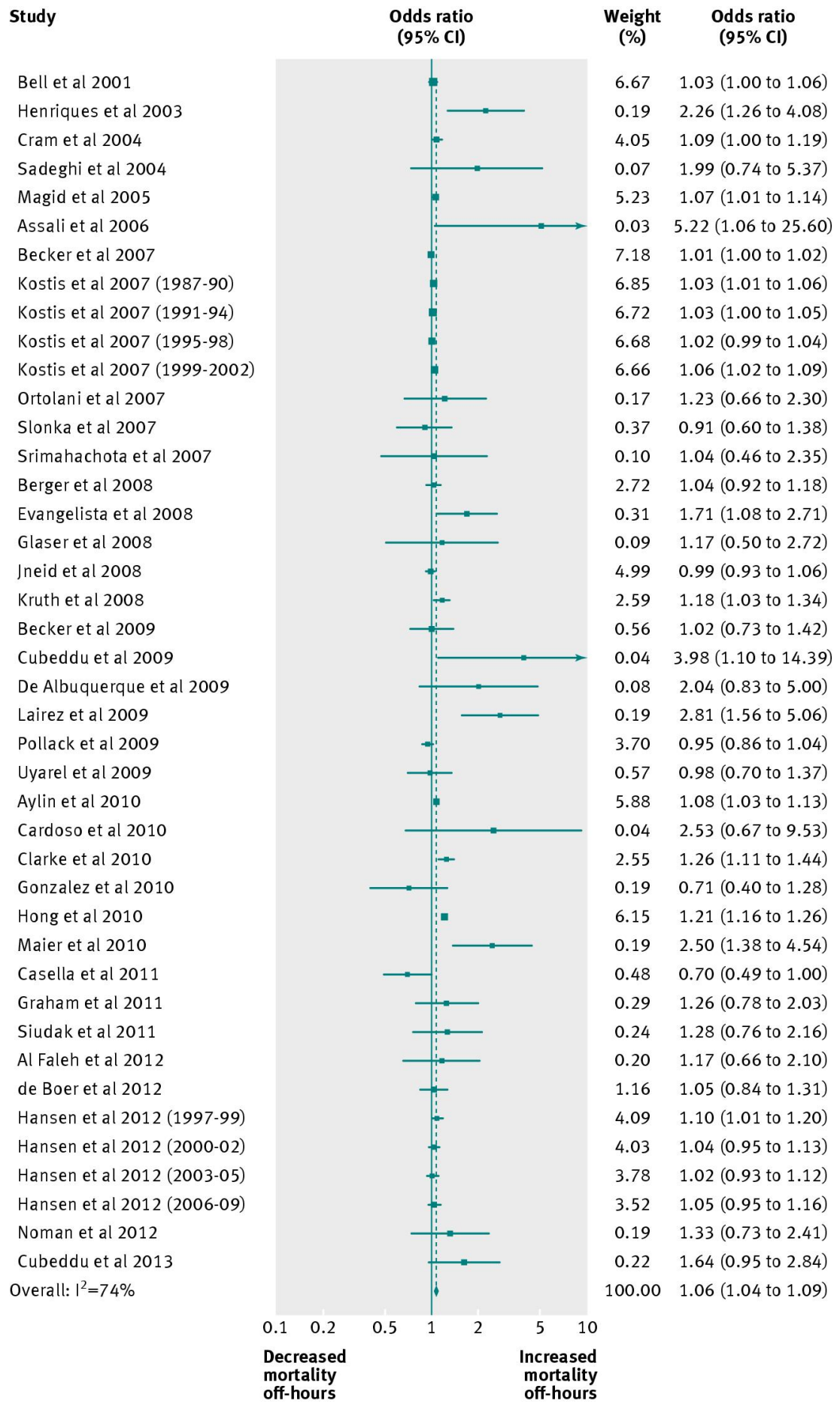

Fig 2 Odds ratio for in-hospital or 30 day mortality due to acute myocardial infarction during off-hours versus regular hours. Forest plot of 42 cohorts. $\mathrm{PCl}=$ percutaneous coronary intervention 


\section{Study}

Magid et al 2005 Assali et al 2006 Garceau et al 2007 Ahmar et al 2008 Jneid et al 2008 Abi Rafeh et al 2009 Al Faleh et al 2012 Overall: $\left.\right|^{2}=41 \%$

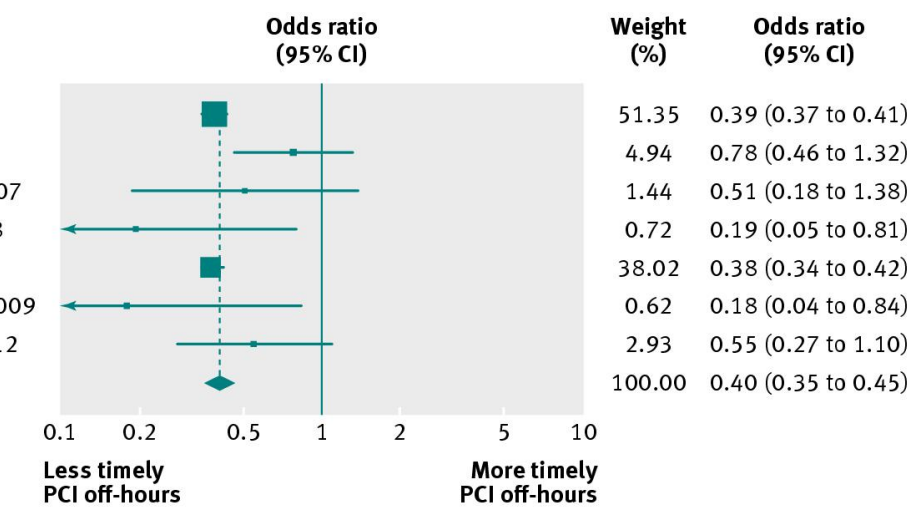

Fig 3 Odds ratio for proportion of STEMI patients with door to balloon times within 90 minutes during off-hours versus regular hours. Forest plot of 7 cohorts 